\title{
Chironomidae (Diptera: Insecta) in oceanic islands: New records for the Azores and biogeographic notes
}

\author{
Pedro Miguel Raposeiro ${ }^{1 *}$, Samantha Jane Hughes ${ }^{2,3}$ and Ana Cristina Costa ${ }^{1}$ \\ ${ }^{1}$ Research Center In Biodiversity and Genetic Resources (CIBIO) - Açores, and Biology Department, University of Azores, \\ 9501-855 Ponta Delgada, Açores, Portugal \\ 2 Centre for Macaronesian Studies (CEM), University of Madeira, Campus da Penteada, Funchal 9000-390, Portugal \\ ${ }^{3}$ Centre for the Research and Technology of Agro-Environment and Biological Sciences, University of Trás os Montes e Alto Douro, \\ Apartado, Apartado 1013, 5001-801 Vila Real, Portugal
}

Received 28 March 2009; Accepted 20 April 2009

\begin{abstract}
Oceanic islands freshwater systems are unique due to their volcanic origin, oceanic situation, catchment morphology and the presence of distinct freshwater communities when compared with continental systems. This study provides an update of Azorean chironomid fauna records, distribution data and includes biogeographical comments, based on collections covering a range of freshwater habitats on several islands over 2005 to 2008. Island species area-relationships or ISAR was performed as a descriptive model for species accumulation patterns in each island in relation to their area. Six new chironimid species records are given for the Azores archipelago: Orthocladiinae: Orthocladius (Eudactylocladius) fuscimanus (Kieffer, 1908), Pseudorthocladius (Pseudorthocladius) curtistylus (Goetghebuer, 1921), Synorthocladius semivirens (Kieffer, 1909), Parachaetocladius abnobaeus (Wülker, 1959); Chironominae: Chironomus (Chironomus) annularis (Meigen, 1818), Parachironomus tenuicaudatus (Malloch, 1915). As a result, the Azorean chironomid fauna has increased from 38 to 44 species, spread across 33 genera. Most recorded chironomids are primarily of western Palaearctic origin; Nearctic, Oriental and Neotropical regions are comparatively poorly represented. A checklist is provided, incorporating and updating previous records. Chirononidae distribution pattern among the islands is analyzed and island species area-relationship (ISAR) analyses, performed to provide a descriptive model for species accumulation patterns in each island, indicated a positive correlation between species richness (number of species) and the area of the Azorean islands, supporting MacArthur and Wilson's equilibrium theory of island biogeography. Chironomidae could be promising for searching candidate bioindicators to answer the demand of Water Frame Directive.
\end{abstract}

Key words: Island species-area relationship (ISAR) / Insecta / Chironomidae / Azores / oceanic islands / distribution

\section{Introduction}

The Chironomidae comprise a widely distributed group of insects with an aquatic larval stage that often occurs high densities and diversity in freshwater and marine environments (Pinder, 1986; Ashe et al., 1987; Armitage et al., 1995; Osborne et al., 2000). The diversity of chironomid species is exceptionally high with an estimated worldwide number of 15000 species (Cranston and Pinder, 1995).

The occurrence of freshwater insects in oceanic islands has always raised interest concerning mechanisms of dispersal, colonization and evolution and even their absence

\footnotetext{
* Corresponding author: raposeiro@uac.pt
}

is used as evidence concerning mechanisms that govern those processes (Bilton et al., 2001; Cowie and Brenden, 2006). Owing to their isolation and lack of contact with continental landmasses, oceanic islands are natural laboratories for the study of patterns and processes of dispersal, colonization and speciation and the testing of ecological, evolutionary and biogeographical theories such as the dynamic equilibrium model of island biogeography (MacArthur and Wilson, 1967) and more recently the general dynamic theory of oceanic island biogeography (Triantis et al., 2008; Whittaker et al., 2008; Borges and Hortal, 2009).

The Azores are part of the Macaronesian faunal subregion that also includes Madeira, the Canaries and the Cape Verde Islands. They are the most remote 


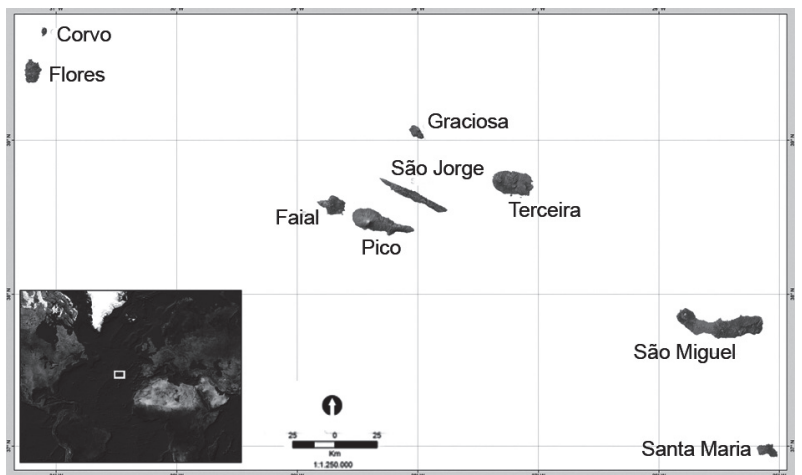

Fig. 1. The Azores archipelago.

archipelago in the North Atlantic (Fig. 1), situated 1300 km from the European mainland and $1900 \mathrm{~km}$ from the American continent, and constitute an ideal system to test biogeographical hypothesis. As is typical of island ecosystems, the insect fauna of the Azores is depauperated in comparison to continental systems, due to the islands' volcanic origin, extreme isolation, small size, geological youth and the torrential character of freshwater environments (Borges and Brown, 1999). These strong environmental filters limit the range of freshwater organisms able to colonize island stream systems. The Azorean freshwater fauna is dominated by insect orders, in particular the Diptera. However, some taxonomic groups are absent (e.g. Plecoptera) or represented by orders containing only a single species (e.g. Ephemeroptera-Cloeon dipterum) or families containing few genera (e.g. HydroptilidaeHydroptila fortunate, $H$. vectis, Oxyethira falcate) or even a single species (e.g. Limnephilidae-Limnephilus atlanticus). The most diverse Azorean dipteran family is Chironomidae (Borges et al., 2005).

The Azorean chironomid fauna has been studied by several workers during the last century. Frey (1944) and Stora (1945) reported on Azorean Chironomidae, while Freeman (1959) provided additional records from collections made by Brinck and Dahl from the Lund University Expedition to Azores and Madeira in 1957. Cobo et al. (2002) applied current taxonomy to the Azorean records compiled by Kehlmaier (1998). More recent records of Chironomidae were provided by Murray et al. (2004) from collections made during the summer of 1997 and the autumn of 1998. Murray et al. (2004) in their review of Chironomidae from the Azores gave a total of 49 species, including species regarded as nomen dubium and genus level identification. By excluding the genus level and nomen dubium Murray et al. (2004) recorded 38 species for the Azores archipelago, the same number of species that Diaz et al. (2005) gave in their compiled list. The number of species known from each island varies from 5 in Corvo to 30 in São Miguel.

This study provides an update of Azorean chironomid fauna records, distribution data and includes biogeographical comments, based on collections covering a range of freshwater habitats on several islands over 2005 to 2008. Island species area-relationships or ISAR was performed as a descriptive model for species accumulation patterns in each island in relation to their area.

\section{Methods}

\section{Area of study: The Azores}

The archipelago of the Azores (latitude: $36^{\circ} 55^{\prime}-$ $39^{\circ} 43^{\prime} \mathrm{N}(530 \mathrm{~km})$; longitude: $25^{\circ} 00^{\prime}-31^{\circ} 17^{\prime} \mathrm{W}(320 \mathrm{~km})$ ), comprises nine islands and several islets, astride the Mid Atlantic Ridge. São Miguel and Corvo are the largest and smallest islands with $745 \mathrm{~km}^{2}$ and $17 \mathrm{~km}^{2}$, respectively. Santa Maria is the Southern and Easternmost Island $\left(37^{\circ} \mathrm{N}, 25^{\circ} \mathrm{W}\right)$. The nine islands form three groups (Fig. 1) separated by 1000 to $2000 \mathrm{~m}$ deep sea channels. The Azorean climate is oceanic and temperate with mean annual temperatures of $14-18{ }^{\circ} \mathrm{C}$ and mean annual precipitation of 740-2400 mm (Bettencourt, 1979). Wind patterns differ among groups of islands with South and Southwest prevailing winds in Western and Central groups, whereas in Eastern group winds predominate from North and Northeast directions. Strongest winds blow from South and West largely surpassing the wind average speed of $16.8 \mathrm{~km} \cdot \mathrm{h}^{-1}$ (Porteiro, 2000).

Geologically, the Azores comprise a 20-36 Myr old volcanic plateau; the oldest rocks emerged 8.12 Myr ago (Santa Maria island) while the youngest (Pico island) is about 0.250 Myr old (Borges and Brown, 1999; Quartau, 2007). Recurrent volcanic activity in the archipelago may have promoted extinction, fragmentation, (re)colonization, and allopatric speciation events (Cook, 1996). Geologically these islands are the youngest of Macaronesia (biogeographical region that comprehends the archipelago of Azores, Madeira, Canary Islands and Cape Verde).

Lotic systems are characterized by small (most less than $10 \mathrm{~km}^{2}$ ), short and steep watersheds (Smith et al., 2003; Hughes, 2005; Hughes and Malmqvist, 2005) with short, steep, deeply incised streams. Permanent streams, fed by lakes or spring waters, exist only in Santa Maria, São Miguel, São Jorge, Faial and Flores islands (DROTRH/INAG, 2001). The Azores is particularly rich in lentic habitats, with over 88 lakes (see Porteiro, 2000), that occupy $0.4 \%$ of the regional territory located in São Miguel, Terceira, Pico, Flores and Corvo. Lentic systems tend to be flooded volcanic craters, caldeiras and maars (shallow but broad craters formed by explosive excavation into older lithologies during phreatomagmatic eruptions (Azevedo, 1998; Nunes, 1999)).

\section{Data analysis}

Collections were made at 69 sites, covering several types of freshwater habitat in seven of the nine islands of the Azorean archipelago (site locations, dates and collection made are given in Table 1). Field programmes were carried out in 2006 (17 sites), 2007 (24 sites) and 2008 (27 sites). Qualitative samples were collected by scooping 
floating debris with a hand net (mesh size: $250 \mu \mathrm{m}$ ) along the surface waters of ponds, lakes, streams, reservoirs and animal drinking troughs (Ferrington et al., 1991; Wilson, 1996; Wilson and Ruse, 2005). Samples were collected using drift-nets with $250 \mu \mathrm{m}$ were used in some streams (Hardwick et al., 1995; Wong et al., 2004). After collection, samples were readily sieved (mesh size: $250 \mu \mathrm{m}$ ) and preserved in $70 \%$ ethanol. Material was sorted and identified in the laboratory using keys by Langton (1991), Langton and Visser (2003) and Bouchard and Ferrington Jr. (2008).

Island species area-relationships or ISAR were analyzed utilizing the power function (Whittaker and Fernandez-Palacios, 2007) as a descriptive model for species accumulation patterns, described by $S=c A^{z}$, expressed as a log-log model: $\log _{10} Y=c+z \log _{10} X$, where $X$ is the explanatory variable number of units of area $(A)$, and $Y$ is the response variable species richness $(S)$. The intercept $(c)$ is the expected number of species in a unit area and $Z$ is the rate of increase of species with area.

The confidence interval for the regression gives the range of variable values computed for the region containing the true relationship between the dependent and independent variables, for the specified level of confidence was calculated by SPSS 15.0.

\section{Results}

A total of 32 Chironomidae species, distributed among 24 genera, 3 subfamilies and 5 tribes, were collected as a result of this study (Table 2, available at www.limnologyjournal.org). The Orthocladiinae (16 taxa) showed the greatest richness, followed by Chironominae (12 taxa) and Tanypodinae (4 taxa). Far more species were exclusive to lotic systems (52\%) than lentic systems $(16 \%)$, while $32 \%$ were found in both systems.

There were new records for seven islands, i.e. some of the newly recorded species had already been recorded from other islands in the archipelago: 4 species for Corvo, 8 species for Flores, 8 species for Faial, 7 species for Pico, 5 species for São Jorge, 10 species for São Miguel and 16 species for Santa Maria (Table 3, available at www. limnology-journal.org).

Six species comprised new records for the Azores archipelago; the following section provides brief notes on the records with information on their wider distribution patterns.

\section{Orthocladiinae}

The Orthocladiinae occupies the widest range of habitats of all chironomids (Oliver, 1971; Oliver and Dillon, 1997) and is described primarily as a cold-adapted subfamily, although orthoclads also occur in many warm habitats. Larvae occur in all types of running and standing waters.
Orthocladius (Eudactylocladius) fuscimanus (Kieffer, 1908)

Orthocladius (Eudactylocladius) sp. was previously collected by Murray et al. (2004) from São Miguel, Terceira and Flores. Exuviae of this species were collected from sites on Santa Maria, São Miguel, Pico, Faial and Flores. This species was one of the most abundantly occurring taxa at stream sample sites. It has a circum-Mediterranean distribution (Langton and Visser, 2003) and also occurs on the Canary Islands (Baez and Armitage, 1990) and Madeira (Hughes, 2008).

\section{Pseudorthocladius (Pseudorthocladius) curtistylus (Goetghebuer, 1921)}

Exuviae of this Holartic species (Langton and Visser, 2003) were collected from Ribeira do Grande e Ribeira Cachaço on Santa Maria. Murray et al. (2004) recorded a single Pseudorthocladius adult male collected over rocks on the marine shoreline at Ponta Delgada (São Miguel). The species was reported from Madeira by Hughes and Murray (2000), is also occurs on the Canary Islands (Oromí and Báez, 2001).

\section{Parachaetocladius abnobaeus (Wülker, 1959)}

A new generic record for the Azores. The characteristic pupal exuviae of the species were collected from streams in Flores and São Miguel. The species is present in continental Europe but Holartic in origin (Langton and Visser, 2003).

\section{Synorthocladius semivirens (Kieffer, 1909)}

A new record for this monospecific genus. Exuviae were collected in abundance from streams in Faial, Flores and São Miguel. According to Saether and Spies (2004) it is a Palaearctic species, present in Madeira (Hughes, 2008).

\section{Chironominae}

Most species of Chironominae are essentially warmadapted and live in standing water, though they are not uncommon in cool habitats and in running waters (Oliver and Dillon, 1997).

\section{Chironomus (Chironomus) annularius (Meigen, 1818)}

The first record of this species for Macaronesia. This species was collected from lakes of Flores and São Miguel, and water troughs in Flores, São Jorge and Pico; it is abundant in enriched lentic systems. Exuviae of $C$. riparius were obtained together with a second species tentatively identified as C. cf annularius (Murray et al., 2004) from an artificial pool at Santa Cruz Community Centre (Flores). C. annularius is an Holartic species, widespread in Europe (Langton and Visser, 2003). 
Table 1. Sites location, dates and codes of collections.

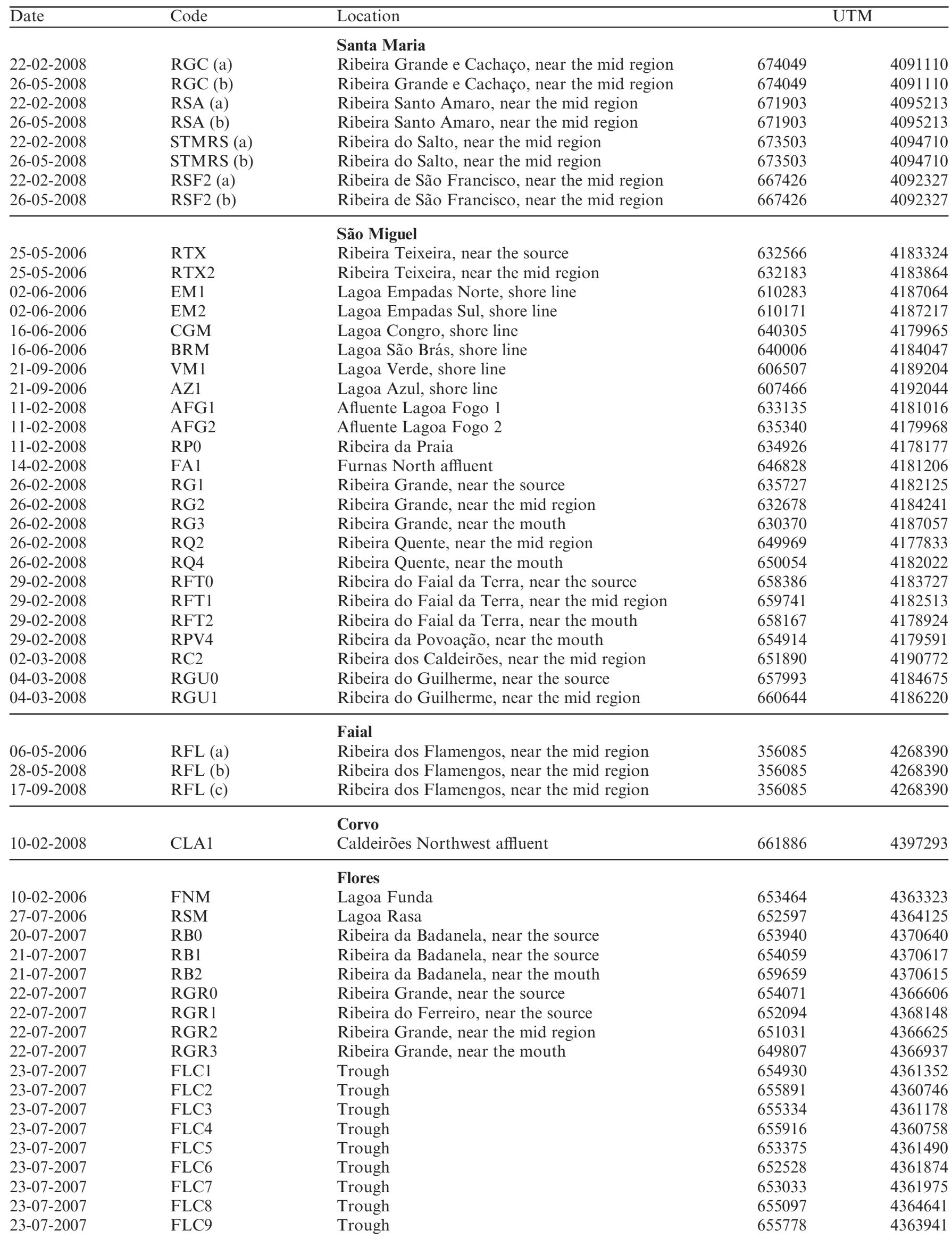


Table 1. (Continued).

\begin{tabular}{|c|c|c|c|c|}
\hline Date & Code & Location & & \\
\hline $23-07-2007$ & FLC10 & Trough & 657103 & 4366011 \\
\hline 23-07-2007 & FLC11 & Trough & 657654 & 4366185 \\
\hline 23-07-2007 & FLC12 & Trough & 658016 & 4366144 \\
\hline 23-07-2007 & FLC13 & Trough & 660332 & 4367755 \\
\hline & & Pico & & \\
\hline 05-05-2006 & ROS & Lagoa Rosada & 396412 & 4254546 \\
\hline 05-05-2006 & CAI & Lagoa do Capitão & 384894 & 4260829 \\
\hline 05-05-2006 & PAU & Lagoa do Paúl & 392334 & 4254113 \\
\hline 07-08-2007 & PIC 2 & Pico 2 & 373551 & 4261978 \\
\hline 07-08-2007 & PIC 3 & Pico 3 & 392085 & 4256181 \\
\hline & & São Jorge & & \\
\hline $14-08-2006$ & Jor 2 & Trough & 390280 & 4288157 \\
\hline $14-08-2006$ & Jor 3 & Trough & 399622 & 4282255 \\
\hline $14-08-2006$ & Jor 7 & Trough & 414107 & 4276467 \\
\hline 13-08-2007 & JR-SJOR1 & Trough & 427667 & 4267081 \\
\hline 13-08-2007 & JR-SJOR2 & Trough & 395147 & 4283713 \\
\hline $13-08-2007$ & JR-SJOR3 & Trough & 390999 & 4286387 \\
\hline
\end{tabular}

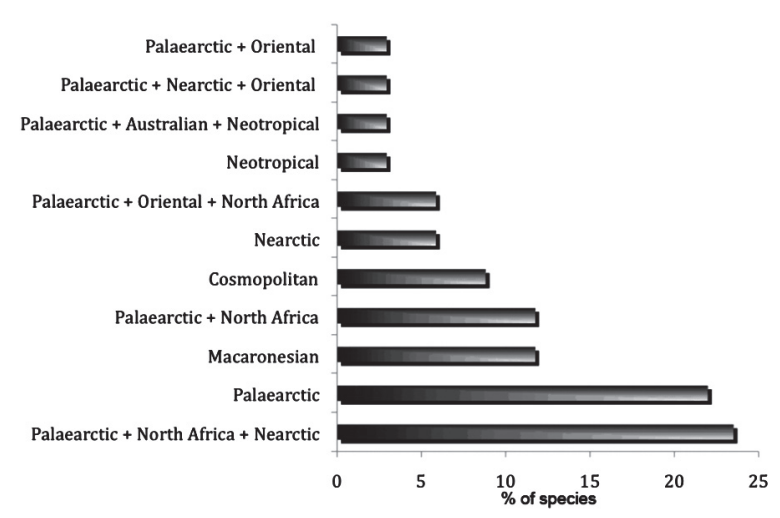

Fig. 2. Biogeographic origin of Azorean chironomids. Percentages of each origin are shown.

\section{Parachironomus tenuicaudatus (Malloch, 1915)}

The first record of this species for the Macaronesia. $P$. tenuicaudatus was found in Ribeira da Praia in São Miguel and is now the first generic record for the Azores. According to Langton and Visser (2003) it is an Holartic species characteristic of lakes.

\section{Biogeographic origin - break down}

The Azorean chironomid fauna is predominantly Western Palaearctic in origin (see Fig. 2) with most taxa originating from Europe. Nearctic and North African taxa are less well represented. A smaller number of taxa occurs across several biogeographical regions. For example Chironomus riparius (Meigen, 1804) and Cricotopus (Isocladius) sylvestris (Fabricius, 1794) have a worldwide distribution, while Smittia aterrima (Meigen, 1818) is found in Palaearctic, Nearctic and Oriental regions. Thalassomya frauenfeldi (Schiner, 1856) is a Neotropical species.

Macaronesian species constitute $12 \%$ of the chironomid Azorean fauna. Cardiocladius freyi (Stora in Frey,
1936) and Thalassosmittia atlantica (Stora in Frey, 1936) occur in the Azores, Madeira and Canary Islands. Diamesa alata (Stora, 1945) and Microsepta freyi (Stora, 1945) are known from the Azores and Madeira. No Azorean endemic species are yet described.

\section{Species-area distributions}

A positive correlation $(r=0.88, n=9, P=0.002)$ was evident between species richness (number of species) and island area (Table 3). The relationship between island area $A$ and species number $S$ for the nine islands was best described by a power function equation ISAR (1):

$$
\log (S)=0.5135+0.3597 * \log (A) .
$$

Flores was a clear outlier in this relationship (outside the 99\% confidence interval), exhibiting higher than expected species richness in relation to its surface area (Fig. 3).

\section{Discussion}

Based on species level identifications only (i.e. excluding nomen dubium and genus level identification), this study increases the number of species occurring in the Azores from 38 to 44 (Table 4), distributed across 33 genera and five subfamilies Telmatogetoninae, Tanyponidae, Orthocladiinae, Diamesinae and Chironominae (Fig. 4). The number of recorded species for each island is now 40 for São Miguel (an increase of 25\%), 29 for Terceira, 28 for Flores (an increase of 28\%), 22 for São Jorge (an increase of 22\%), 18 for Faial (an increase of $33 \%$ ), 20 for Pico (an increase of 35\%), 14 for Santa Maria (an increase of $89 \%$ ) and 9 for Corvo (an increase of $44 \%$ ). The total number of chironomid species is still lower than in the other Macaronesian archipelagos; Madeira has 60 species (Hughes, 2008), while the Canary Islands has 58 (Baez and Garcia, 2001). 
Table 4. Updated list of chironomid for the Azores archipelago.

\begin{tabular}{|c|c|c|c|c|c|c|c|c|c|}
\hline & COR & FLO & FAI & $\mathrm{PIC}$ & GRA & SJG & TER & SMG & SMR \\
\hline \multicolumn{10}{|l|}{ Chironominae } \\
\hline $\begin{array}{l}\text { Chironomus (Chironomus) annularius } \\
\text { (Meigen, 1818) }\end{array}$ & & & & N Isl & & $\mathrm{NAz}$ & & $\mathrm{N} \mathrm{Az}$ & \\
\hline Chironomus cingulatus (Meigen, 1818) & & N Isl & N Isl & & $\mathrm{P}$ & N Isl & $\mathrm{P}$ & $\mathrm{C}$ & \\
\hline Chironomus dorsalis (Meigen, 1818) & & $\mathrm{C}$ & $\mathrm{P}$ & N Isl & & $\mathrm{P}$ & $\mathrm{P}$ & $\mathrm{C}$ & \\
\hline Chironomus riparius (Meigen, 1804) & & $\mathrm{C}$ & $\mathrm{P}$ & $\mathrm{P}$ & $\mathrm{P}$ & & $\mathrm{P}$ & $\mathrm{C}$ & N Isl \\
\hline Chironomus venustus (Staeger, 1839) & & & & & $\mathrm{P}$ & $\mathrm{P}$ & $\mathrm{P}$ & $\mathrm{P}$ & \\
\hline Glyptotendipes barbipes (Staeger, 1839) & & & & & $\mathrm{P}$ & & $\mathrm{P}$ & $\mathrm{C}$ & \\
\hline Glyptotendipes pallens (Meigen, 1804) & & & & & $\mathrm{P}$ & & $\mathrm{P}$ & N Isl & \\
\hline Micropsectra junci (Meigen, 1818) & $\mathrm{P}$ & $\mathrm{P}$ & $\mathrm{P}$ & $\mathrm{C}$ & & $\mathrm{C}$ & $\mathrm{P}$ & $\mathrm{C}$ & \\
\hline Micropsectra lindrothi (Goetghebuer, 1931) & & $\mathrm{C}$ & & & & & & N Isl & \\
\hline Parachironomus tenuicaudatus (Malloch, 1915) & & & & & & & & $\mathrm{N} \mathrm{Az}$ & \\
\hline Paratanytarsus grimmii (Schneider, 1885) & & N Isl & N Isl & & & & $\mathrm{P}$ & $\mathrm{N}$ Isl & N Isl \\
\hline Polypedilum nubeculosum (Meigen, 1818) & & & $\mathrm{N}$ Isl & $\mathrm{P}$ & & & $\mathrm{P}$ & $\mathrm{C}$ & \\
\hline Polypedilum nubifer (Skuse, 1889) & & & & & $\mathrm{P}$ & & $\mathrm{P}$ & $\mathrm{N}$ Isl & $\mathrm{N}$ Isl \\
\hline \multicolumn{10}{|l|}{ Diamesinae } \\
\hline Diamesa alata (Stora, 1945) & & & $\mathrm{P}$ & & & & $\mathrm{P}$ & $\mathrm{P}$ & \\
\hline \multicolumn{10}{|l|}{ Orthocladiinae } \\
\hline Camptocladius stercorarius (De Geer, 1776) & N Isl & $\mathrm{C}$ & $\mathrm{P}$ & $\mathrm{P}$ & & $\mathrm{P}$ & $\mathrm{P}$ & $\mathrm{C}$ & N Isl \\
\hline Cardiocladius freyi (Stora in Frey, 1936) & & $\mathrm{C}$ & & & & $\mathrm{P}$ & $\mathrm{P}$ & $\mathrm{C}$ & N Isl \\
\hline Chaetocladius melaleucus (Meigen, 1818) & $\mathrm{C}$ & $\mathrm{C}$ & N Isl & & & & $\mathrm{P}$ & $\mathrm{C}$ & \\
\hline Cricotopus (Isocladius) ornatus (Meigen, 1818) & & & & N Isl & & & $\mathrm{P}$ & $\mathrm{C}$ & N Isl \\
\hline $\begin{array}{l}\text { Cricotopus (Isocladius) sylvestris } \\
\text { (Fabricius, 1794) }\end{array}$ & & & & & $\mathrm{P}$ & $\mathrm{N}$ Isl & $\mathrm{P}$ & $\mathrm{C}$ & N Isl \\
\hline Eukiefferiella gracei (Edwards, 1929) & & $\mathrm{P}$ & $\mathrm{P}$ & $\mathrm{P}$ & & $\mathrm{P}$ & & $\mathrm{P}$ & \\
\hline Halocladius varians (Staeger, 1839) & & $\mathrm{P}$ & $\mathrm{P}$ & $\mathrm{P}$ & $\mathrm{P}$ & $\mathrm{P}$ & & $\mathrm{P}$ & \\
\hline Limnophyes minimus (Meigen, 1818) & & $\mathrm{C}$ & $\mathrm{P}$ & $\mathrm{P}$ & & $\mathrm{P}$ & $\mathrm{P}$ & $\mathrm{C}$ & N Isl \\
\hline $\begin{array}{l}\text { Metriocnemus carmencitabertarum } \\
\text { (Langton and Cobo, 1997) }\end{array}$ & & & & & & & $\mathrm{P}$ & & \\
\hline Metriocnemus fuscipes (Meigen, 1818) & & $\mathrm{P}$ & $\mathrm{P}$ & $\mathrm{P}$ & & $\mathrm{P}$ & $\mathrm{P}$ & $\mathrm{P}$ & \\
\hline $\begin{array}{l}\text { Orthocladius (Eudactylocladius) fuscimanus } \\
\text { (Kieffer, 1908) }\end{array}$ & & $\mathrm{N} \mathrm{Az}$ & $\mathrm{N} \mathrm{Az}$ & $\mathrm{N} \mathrm{Az}$ & & & & $\mathrm{N} \mathrm{Az}$ & $\mathrm{N} \mathrm{Az}$ \\
\hline Parachaetocladius abnobaeus (Wülker 1959) & & $\mathrm{NAz}$ & & & & & & N Az & \\
\hline Parametriocnemus stylatus (Kieffer, 1924) & & $\mathrm{C}$ & $\mathrm{P}$ & & & & $\mathrm{P}$ & $\mathrm{C}$ & N Isl \\
\hline Psectrocladius limbatellus (Holmgren, 1869) & N Isl & N Isl & & N Isl & & N Isl & & $\mathrm{C}$ & \\
\hline Psectrocladius sordidellus (Zetterstedt, 1838) & $\mathrm{P}$ & $\mathrm{C}$ & $\mathrm{C}$ & $\mathrm{N}$ Isl & & $\mathrm{P}$ & $\mathrm{P}$ & $\mathrm{C}$ & \\
\hline $\begin{array}{l}\text { Pseudorthocladius (Pseudorthocladius) } \\
\text { curtistylus (Goetghebuer, 1921) }\end{array}$ & & & & & & & & & $\mathrm{N} \mathrm{Az}$ \\
\hline Pseudosmittia brevifurcata (Edwards, 1932) & & & & $\mathrm{P}$ & $\mathrm{P}$ & $\mathrm{P}$ & & & \\
\hline Rheocricotopus atripes (Kieffer, 1913) & & $\mathrm{C}$ & $\mathrm{C}$ & & & $\mathrm{C}$ & $\mathrm{P}$ & $\mathrm{C}$ & N Isl \\
\hline Synorthocladius semivirens (Kieffer, 1909) & & $\mathrm{NAz}$ & $\mathrm{NAz}$ & & & & & $\mathrm{NAz}$ & \\
\hline Smittia aterrima (Meigen, 1818) & & & & & & & & $\mathrm{P}$ & \\
\hline Smittia contingens (Walker, 1956) & & & & & & & & $\mathrm{P}$ & \\
\hline Thalassosmittia atlantica (Stora in Frey, 1936) & $\mathrm{P}$ & $\mathrm{P}$ & $\mathrm{P}$ & $\mathrm{P}$ & $\mathrm{P}$ & & $\mathrm{P}$ & $\mathrm{P}$ & \\
\hline Thienemannia gracei (Edwards, 1929) & & & & & & $\mathrm{P}$ & & & $\mathrm{P}$ \\
\hline Thienemanniella clavicornis (Kieffer, 1911) & N Isl & $\mathrm{C}$ & & & & & $\mathrm{P}$ & $\mathrm{C}$ & N Isl \\
\hline \multicolumn{10}{|l|}{ Tanypodinae } \\
\hline Macropelopia nebulosa (Meigen, 1804) & & $\mathrm{P}$ & $\mathrm{P}$ & & & $\mathrm{P}$ & $\mathrm{P}$ & $\mathrm{P}$ & \\
\hline Paramerina cingulata (Walker, 1856) & $\mathrm{N}$ Isl & N Isl & N Isl & & & N Isl & $\mathrm{P}$ & $\mathrm{C}$ & $\mathrm{N}$ Isl \\
\hline Procladius choreus (Meigen, 1804) & & $\mathrm{N}$ Isl & & $\mathrm{N}$ Isl & $\mathrm{P}$ & & $\mathrm{P}$ & $\mathrm{N}$ Isl & $\mathrm{N}$ Isl \\
\hline Telmatopelopia nemorum (Goetghebuer, 1921) & & $\mathrm{C}$ & N Isl & $\mathrm{C}$ & & $\mathrm{C}$ & $\mathrm{P}$ & $\mathrm{P}$ & $\mathrm{C}$ \\
\hline Zavrelimyia nubila (Meigen, 1830) & & $\mathrm{C}$ & $\mathrm{C}$ & $\mathrm{P}$ & & $\mathrm{C}$ & & $\mathrm{C}$ & N Isl \\
\hline \multicolumn{10}{|l|}{ Telmatogeninae } \\
\hline Thalassomyia frauenfeldi (Schiner, 1856) & $\mathrm{P}$ & $\mathrm{P}$ & $\mathrm{P}$ & $\mathrm{P}$ & & $\mathrm{P}$ & $\mathrm{P}$ & $\mathrm{P}$ & \\
\hline Previous records $(\mathrm{P})$ & 4 & 7 & 13 & 11 & 11 & 13 & 29 & 11 & 1 \\
\hline Confirmed in island $(\mathrm{C})$ & 1 & 13 & 3 & 2 & 0 & 4 & 0 & 19 & 1 \\
\hline New in island ( $\mathrm{N}$ Isl) & 4 & 5 & 6 & 6 & 0 & 4 & 0 & 5 & 14 \\
\hline New in Azores (N Az) & 0 & 3 & 2 & 1 & 0 & 1 & 0 & 5 & 2 \\
\hline Total species & 9 & 28 & 24 & 20 & 11 & 22 & 29 & 40 & 18 \\
\hline
\end{tabular}




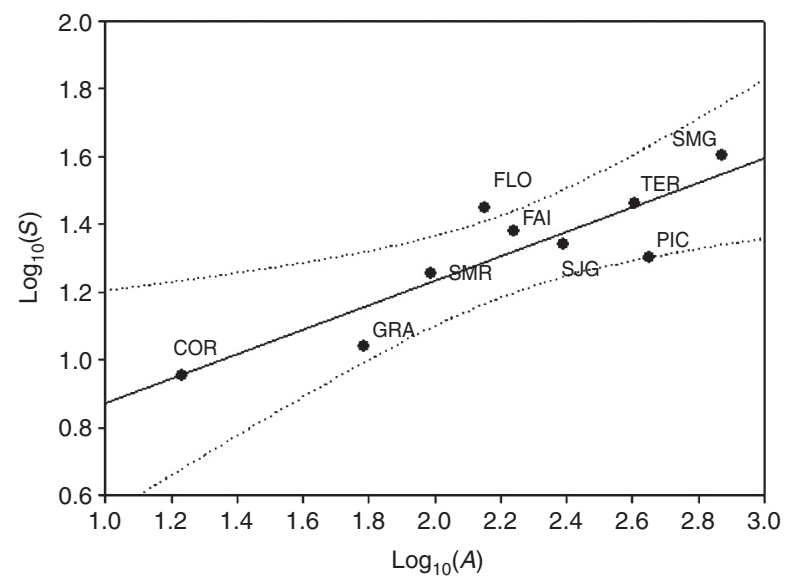

Fig. 3. Species-area curve $\log (S)=0.5135+0.3597 * \log (A)$. Regression line indicates a significant linear relationship at $P<0.002$ and $\mathrm{R}^{2}=0.78$. Dot lines are $99 \%$ interval confidence.

As a result of the collection and examination of pupal exuviae, this study confirmed the presence of 21 species listed by previous authors (Frey, 1944; Stora, 1945; Freeman, 1959; Kehlmaier, 1998; Murray et al., 2004; Diaz et al., 2005). Of the six new records for the Azores, five were exclusive to lotic systems.

Patterns of insular faunal assemblage are the result of factors related to island geography (e.g. area, latitude, altitude, isolation) and island ecology (e.g. geology, biotope availability, land use), but also reflect the biological characteristics of colonizing organisms (e.g. mobility, colonization capability, life cycle). Patterns of organism dispersal in oceanic systems are related to ocean currents, predominant wind patterns (trade winds, hurricane tracks), the geographical position of islands (acting as possible stepping stones) and bird migration routes (mainly eggs attached to feet and feathers). Bilton et al. (2001) separated different mechanisms of dispersal into two groups: (1) the active dispersal that self generates movements and (2) the passive dispersal that is achieved by the use of an external agent. In Azorean freshwater systems dispersal by active or passive drift takes place at the reach scale, over time scales, may allow successful colonization of freshwater system. Chironomidae as active flying adults can disperse over larger areas, allowing the colonization of other freshwater systems.

The increase in chironomid species richness with increasing island area is consistent with the observations reported by Borges et al. (2005) for epigean arthropods, canopy arthropods and epigean bryophytes in Azores. It is also in agreement with the area-diversity relationship of the equilibrium theory of island biogeography (MacArthur and Wilson, 1967). The theory postulates that the number of species $(S)$ is related to the surface area $(A)$ by the equation $S=C A^{z}$, where $C$ is a constant that varies among taxa and $z$ is an empirical constant. The $z$ value found for chironomidae species in this study is 0.36 , similar to the value determined by MacArthur and Wilson (1967) for oceanic islands (oceanic islands varies between 0.24 to 0.34 ), indicating the rate at which the species

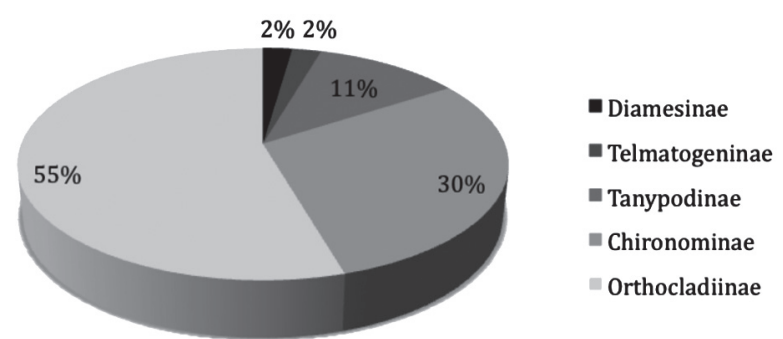

Fig. 4. Representation of subfamilies of chironimids in the Azores archipelago.

richness increases with island area. However, in the case of freshwater invertebrates, the quantity of freshwater is also a vital consideration. For example, the high species richness of Flores Island (Fig. 3) may be due to the availability of a very large quantity of freshwater habitats in relation to its surface area, providing favourable colonization conditions for incoming species. In spite of its small area Flores has several lakes, permanent streams, wetlands and peat bogs. It is also the island with the highest levels of precipitation in the Azores archipelago.

As previously mentioned, the Azorean Chironomid fauna is typically Palaearctic, with widespread species that exhibit great dispersal ability. The lack of single-island endemic chironomid species within the Archipelago compared to the flora, estimated at $7.2 \%$ of endemic species (Borges et al. 2005), indicates substantial inter-island chironomid dispersal capacity.

All European freshwater ecologists should be familiar with the Water Framework Directive - WFD, which establishes a framework for Community action in the field of water policy. The WFD legislates the provision of mechanisms to prevent further deterioration, and to protect and enhance the status of aquatic ecosystems. The Azores, as a Portuguese autonomous region is obliged to implement the WFD, despite the relatively increase in recent studies of the Azorean macroinvertebrate lotic communities (e.g. Murray et al., 2004; Raposeiro and Costa, 2004; Gonçalves et al., 2005) applied a range of well known macroinvertebrate biotic indices to the freshwater fauna of the archipelago, but achieved disappointing results due to the particularities of this distinctly insular local fauna. The Chironomidae is the most abundance and diverse macroinvertebrate family occurring across several types of freshwater systems of the Azores Archipelago, constituting a promising candidate for ecological assessment. For example the Chironomid Pupal Exuviae Technique (CPET) could be possibly be tested and adapted in the archipelago. CPET is based upon the premise that aquatic chironomid larvae are exposed to local environmental conditions and that the winged adults ensure effective dispersal and colonisation and was successfully applied to Madeiran lotic systems (Hughes, 2003).

Acknowledgements. Part of this study was financed by Fundação para a Ciência e Tecnologia (FCT - SFRH / BD / 28798 / 2006). We thank Dr. João Ramos and João Brum for collecting part of the chironomid pupal exuviae data and Dr. Paulo Borges for 
helpful comments and suggestions that improved the scope and content of the manuscript.

\section{REFERENCES}

Armitage P., Cranston P.S.V. and Pinder L.C.V., 1995. The Chironomidae - The biology and ecology of non-biting midges, Chapman and Hall, London, xii +572 p.

Ashe P., Murray D.A. and Reiss F., 1987. The zoogeographical distribution of Chironomidae. Ann. Limnol. - Int. J. Lim., 23, 27-60.

Azevedo J.M.M., 1998. Geologia e hidrologia da Ilha das Flores (Açores - Portugal), Dissertação para a obtenção do grau de Doutor em Geologia, Departamento de Ciências da Terra, Universidade de Coimbra, Coimbra, 403 p.

Baez M. and Armitage P.D., 1990. Chironomidae (Diptera, Nematocera) from Madeira. Bocagiana, 135, 1-6.

Baez M. and Garcia A., 2001. Chironomidae. In: Zamora I.I., Esquivel J.L.M., Nieves Z.P. and M.A. Hernández (eds.), Lista de especies de Canarias (hongos, plantas y animales terrestres), Consejeria de Politica Territorial y Medio Ambiente del Gobierno de Canarias, Tenerife, 253 p.

Bettencourt M.L., 1979. O clima dos Açores como recurso natural na aplicação especialmente em agricultura e indústria do turismo, Instituto Nacional de Meteorologia e Geofísica, Lisboa, 63 p.

Bilton D.T., Freeland J.R. and Okamura B., 2001. Dispersal in freshwater invertebrates. Ann. Rev. Ecol. Syst., 32, 159-181.

Borges P.A.V. and Brown V.K., 1999. Effect of island geological age on the arthropod species richness of Azorean pastures. Biol. J. Linn. Soc., 66, 373-410.

Borges P.A.V. and Hortal J., 2009. Time, area and isolation: factors driving the diversification of Azorean arthropods. J. Biogeogr., 36, 178-191.

Borges P.A.V., Vieira V., Dinis F., Jarroca S., Co A., Amaral J., Aarvik L., Ashmole P., Ashmole M., Amorim I.R., André G., Argente M.C., Arraiol A., Cabrera A., Diaz S., Enghoff H., Gaspar C., Mendonça E.P., Gisbert H.M.I., Gonçalves P., Lopes D.H., Melo C., Mota J.A., Oliveira O., Oromí P., Pereira F., Pombo D.T., Quartau J.A., Ribeiro S.P., Rodrigues A.C., Santos A.M.C., Serrano A.R.M., Simões A.M.A., Soares A.O., Sousa A.B., Vieira L., Vitorino A., Wunderlich J., Cunha R., Gabriel R., Martins A.F., Silva L. and Vieira V., 2005. Lista dos Artrópodes (Arthropoda). In: Borges P.A.V. (ed.), Listagem da Fauna e Flora (Mollusca e Arthropoda) (Bryophyta, Pteridophyta e Spermamatophyta) Terrestre dos Açores, Projecto Interreg III B (2000-2006) Atlântico, Direcção Regional do Ambiente, 163-221.

Bouchard Jr. R.W. and Ferrington J.L.C., 2008. Identification Guide and Key to Chironomid Pupal Exuviae in Mongolian Lakes, Chironomid Research Group, p. 72.

Cobo F., Soriano O. and Baez M., 2002. Chironomidae. In: Carles-Tolra M. and Andersen H. (eds.), Catalogo de los Diptera de Espana, Portugal y Andorra (Insecta), Monografias SEA, Zaragoza, 35-44.

Cook L.M., 1996. Habitat, isolation and the evolution of Madeiran land snails. Biol. J. Linn. Soc., 59, 457-470.

Cowie R.H. and Brenden S.H., 2006. Dispersal is fundamental to biogeography and the evolution of biodiversity on oceanic islands. J. Biogeogr., 33, 193-198.
Cranston P.S. and Pinder L.C.V., 1995. Introduction. In: Armitage P.D. (ed.), The Chironomidae: Biology and ecology of non-biting midges, Chapman and Hall, London, $1-7$.

Diaz S., Vieira V. and Baez M., 2005. Diptera. In: Borges P.A.V., Cunha R., Gabriel R., Martins A.F., Silva L. and Vieira V. (eds.), Listagem da Fauna e Flora (Mollusca e Arthropoda) (Bryophyta, Pteridophyta e Spermamatophyta) Terrestre dos Açores, Projecto Interreg III B (2000-2006) Atlântico, Direcção Regional do Ambiente, Ponta Delgada, 211-212.

DROTRH/INAG, 2001. Plano Regional da Água, Relatório Técnico, Versão para Consulta Pública, DROTRH - INAG, Ponta Delgada, 414 p.

Ferrington L.C., Blackwood M.A., Wright C.A., Crisp N.H., Kavanaugh J.L. and Schmidt F.J., 1991. A Protocol for Using Surface-Floating Pupal Exuviae of Chironomidae for Rapid Bioassessment of Changing Water Quality. In: Sediment and Stream Water Quality in a Changing Environment: Trends and Explanations, Vienna, 181-190.

Freeman P., 1959. Chironomidae (Diptera, Nematocera) from Azores and Madeira. Bol. Mus. Mun. Funchal, 12, 5-15.

Frey R., 1944. Tiergeographische Studieb über die Dipterenfauna der Azorean. I. Verzeichnis der bisher von den Azoren bekannten Dipteren. Societas Scientiarum Fennica. Commentationes Biologicae, VIII, 1-114.

Gonçalves V., Raposeiro P. and Costa A.C., 2005. The role of benthic diatoms and macro-invertebrates in the assessment of the ecological status of Azorean freshwaters. International Symposium on assessing the ecological status of rivers, lakes and transitional waters, 34-35.

Hardwick R.A., Cooper P.D., Cranston P.S., Humphrey C.L. and Dostine P.L., 1995. Spatial and temporal distribution patterns of drifting pupal exuviae of Chironomidae (Diptera) in streams of tropical northern Australia. Freshwat. Biol., 34, 569-578.

Hughes S.J., 2003. A study of the freshwater macroinvertebrate fauna of Madeira and their application in a regional ecological monitoring system, Ph.D. Thesis, University of London, UK, 328 p.

Hughes S.J., 2005. Application of the water framework directive to Macaronesian freshwater systems. Biology and Environment. Proc. R. Irish Acad., 105B, 185-193.

Hughes S.J., 2008. Chironomidae (Diptera). In: Borges P.A.V., Abreu C., Aguiar A.M.F., Carvalho P., Jardim R., Melo I., Oliveira P., Sérgio C., Serrano A.R.M. and Vieira P. (eds.), List of the terrestrial fungi, flora and fauna of Madeira and Selvagens archipelagos, Direcção Regional do Ambiente da Madeira and Universidade dos Açores, Funchal and Angra do Heroísmo, 330-331.

Hughes S.J. and Malmqvist B., 2005. Atlantic Island freshwater ecosystems: challenges and considerations following the EU Water Framework Directive. Hydrobiologia, 544, 289-297.

Hughes S.J. and Murray D.A., 2000. New record of Chironomidae to Madeira and comments on possible new forms. Late 20th Century Research on Chironomidae: an Anthology from the 13th International Symposium on Chironomidae, 525-533.

Kehlmaier C., 1998. Data-basis for a check-list of all known Diptera species from the Azores Archipelago (Insecta: Diptera). Bol. Mus. Mun. Funchal, 50, 71-90.

Langton P.G., 1991. A Key to Pupal Exuviae of West Palaeartic Chironomidae, Privately published, Huntington, UK, 386 p. 
Langton P.H. and Visser H., 2003. Chironomidae exuviaeA key to pupal exuviae of the West Palaearctic Region, Expert Center for Taxonomic Information, Amsterdam.

MacArthur R.H. and Wilson E.O., 1967. The theory of island biogeography, Princeton University Press, Princeton, USA, 203 p.

Murray D.A., Hughes S.J., Furse M.T. and Murray W.A., 2004. New records of Chironomidae (Diptera: Insecta) from the Azores, Macaronesia. Ann. Limnol. - Int. J. Lim., 40, 33-42.

Nunes J.C., 1999. A actividade vulcânica na Ilha do Pico do Plistocénio Superior ao Holocénio: mecanismo eruptivo e hazard vulcânico, Dissertação para a obtenção do grau de Doutor em Geologia, Departamento de Geociências, Universidade dos Açores, Ponta Delgada, 357 p.

Oliver D.R., 1971. Life History of the Chironomidae. Ann. Rev. Entomol., 16, 211-230.

Oliver D.R. and Dillon M.E., 1997. Chironomids (Diptera: Chironomidae) of the Yukon Arctic North Slope and Herschel Island. In: Danks H.V. and Downes J.A. (eds.), Insects of the Yukon, Biological Survey of Canada (Terrestrial Arthropods), Ottawa, 615-635.

Oromí P. and Báez M., 2001. División Arthropoda. In: Izquierdo I., Martín J.L., Zurita N. and Arechavaleta M. (eds.), Lista de especies silvestres de Canaries (hongos, plantas y animales terrestres), Consejería de Política Territorial y Medio Ambiente Gobierno das Canarias, 149-284.

Osborne S., Hurrell S., Simkiss K. and Leidi A., 2000. Factors influencing the distribution and feeding of the larvae of Chironomus riparius. Entomol. Exp. Appl., 94, 67-73.

Pinder L.C.V., 1986. Biology of Freshwater Chironomidae. Ann. Rev. Entomol., 31, 1-23.

Porteiro J., 2000. Lagoas dos Açores: elementos de suporte ao planeamento integrado, Dissertação para a obtenção do grau de Doutor em Geografia, Departamento de Biologia, Universidade dos Açores, Ponta Delgada, 344 p.

Quartau R.M., 2007. The insular shelf of Faial: Morphological and sedimentary evolution, Universidade de Aveiro, Aveiro, $301 \mathrm{p}$.
Raposeiro P. and Costa A.C., 2004. Freshwater macroinvertebrate communities from the Azores. 5th International Symposium Fauna and Flora of Atlantic Islands, 60-61.

Saether O.A. and Spies M., 2004. Fauna Europaea: Family Chironomidae Fauna Europaea version 1.1, http://www. faunaeur.org.

Smith G.C., Covich A.P. and Brasher A.M.D., 2003. An Ecological Perspective on the Biodiversity of Tropical Island Streams. BioScience, 53, 1048-1051.

Stora R., 1945. Chironomidae. In: Frey R. (ed.), Tiergeographische Studien über die Dipterenfauna der Azoren. I Verzeichnes der bisher von der Azoren bekannten Dipteren, Soc. scien. fenn. Comment. Biol., 10, 21-30.

Triantis K.A., Nogués-Bravo D., Hortal J., Borges P.A.V., Adsersen H., Fernández-Palacios J.M., Araújo M.B. and Whittaker R.J., 2008. Measurements of area and the (island) species area relationship: new directions for an old pattern. Oikos, 117, 1555-1559.

Whittaker R.J. and Fernandez-Palacios J.M., 2007. Island Biogeography - Ecology, Evolution, and Conservation, Oxford University Press, Oxford, 401 p.

Whittaker R.J., Kostas A.T. and Richard J.L., 2008. A general dynamic theory of oceanic island biogeography. J. Biogeogr., 35, 977-994.

Wilson R.C., 1996. A practical key to the genera of pupal exuviae of the British Chironomidae (Diptera: Insecta), Mudgley Elms, Somerset, 98 p.

Wilson R.S. and Ruse L.P., 2005. A guide to the identification of genera of chironomid pupal exuviae occurring in Britain and Ireland (including common genera from Northern Europe) and their use in monitoring lotic and lentic freshwaters, Freshwater Biological Association, Cumbria, UK, $176 \mathrm{p}$.

Wong D.C.L., Maltby L., Whittle D., Warren P. and Dorn P.B., 2004. Spatial and temporal variability in the structure of invertebrate assemblages in control stream mesocosms. Wat. Res., 38, 128-138. 